\title{
TOWARDS HIGHER ACCURACY FOR ECM HYBRIDIZED WITH LOW FREQUENCY VIBRATIONS USING THE RESPONSE SURFACE METHODOLOGY
}

\author{
S. J. Ebeid', M. S. Hewidy ${ }^{2}$, T. A. El-Taweel ${ }^{2}$ and A. H. Youssef ${ }^{2}$ \\ 1. Ain Shams University, Faculty of Engineering, Cairo, Egypt. \\ 2. Menoufia University, Faculty of Engineering, Shebin El-Kom, Egypt. \\ E-mail: tahaeltaweel@yahoo.com
}

\begin{abstract}
Electrochemical machining (ECM) provides a beneficial alternative for machining complex shapes in advanced materials. However, the relatively low machining accuracy with difficulties in tool design and electrolyte disposal has limited ECM to become a commonly used technology. The present work addresses the improvement of machining accuracy in ECM by hybridizing the process by low frequency vibrations. The study highlights the development of mathematical models for correlating the inter relationships of various machining parameters such as applied voltage, feed rate, back pressure and vibration amplitude on overcut and conicity for achieving high controlled accuracy. This work has been based on the response surface methodology (RSM).

This investigation also highlights the various test results that confirm the validity and correctivness of the developed mathematical models for analyzing the effect of the various process parameters on the overcut and conicity. Experimental results reveal useful relationships between the low-frequency vibration parameters and the ECM inter electrode gap and hence the overcut phenomenon. Although the hybridization element seems to be simple, it has led to a significant improvement in the electrochemical machining accuracy. The results also indicate that the assistance of low-frequency vibrations to the ECM process seems to be promising and competitive specially when sculptured surfaces are required to be produced as found particularly in cavities of dies and also in an industrial era of miniaturization.
\end{abstract}

Key words:

Electrochemical machining (ECM), Dimensional accuracy, Response surface methodology (RSM).

Manuscript received from Dr. T.A.El-Taweel

Accepted on : 20/9/2003

Engineering Research Journal Vol 26, No 4, 2003 Minufiya University, Faculty Of

Engineering, Shebien El-Kom, Egypt, ISSN 1110-1180 


\section{INTRODUCTION}

ECM removes materials based on the priniple of anode electrochemical dissolution. ECM is often used for machining difficult-to-cut materials because electrochemical dissolution is independent of the material hardness and toughness (1-2). Additionally, ECM generates no burrs, no stress, and has a longer tool life, with damage-free machined surface, high material removal rate and surface quality. ECM process originally designed for manufacturing complex shaped components in defense and aerospace industries and could be extended to many other industries such as automotive, forging dies, electric and andsurgical components and recently in miniature manufacturing (3-4).

The main advantages of the ECM process are offset by the poor dimensional control and process stability resulting from the complex and stochastic nature of the interelectrode gap (IEG). The hydrogen gas bubbles and Joule heat genarated in the interelectrode gap cause a varying local electrolyte conductivity and hence non-uniform distribution of the gap (5). The stray removal in ECM adversly affects dimensional accuracy and surface quality of machined component (6). Furthermore, the machining accuracy in ECM is critically depends on the electrolyte flow field distribution. Some flow field disrupting phenomena such as cavitation and striation in electrolyte sometimes result in abnormal dissolution and even sparking. flow worsen the accuracy and the uniformity of the ECM machined product (6).

Many attempts have been made to improve its machining accuracy through solving of the above proplemes. For improving the electrolyte flow condition in the interlelectrode gap and also to reduce the occurrence of cavitations, high electrolyte pressures has been recommended (7). In certain cases, the applied pressure was in the form of pluses (7) in an endevour to increase the turbulence in the electrolytic cell and hence help eradicate flow marks. Pressurized electrolytes purged with gas have also been submitted. The gases used were air, nitrogen, a mixture of the two and $\mathrm{CO}_{2}$ (8-9). Improving of the ECM accuracy has been reported as a result of using complex tool feed motion, it has been termed as pulse cyclic ECM (10). The integration of an orbital movement of workpiece electrode to enhance the ECM accuracy was also adopted (11-12). They reported that orbital ECM distributes the electrolyte flow more uniformly and hence leads to a reduction in the flow field disrupting phenomena that adversely affect machining accuracy.

Hybridization techniques are applied to ECM to improve its performance; the most adequate of these are combinations with EDM, USM and recently the latest being laser-ECM. $(13,14,15)$. The reasons for developing a hybrid machining process are to make use of the combined or mutually enhanced advantages, and to avoid or reduce some adverse effects that the constituent processes produce when they are individually applied (16). The performance index of hybrid machining process may be considerable(17). Literature lacks much about imparting low frequency vibrations to improve ECM manufacturing performance.

Therefore, the present work addresses the improvement of machining accuracy in ECM by hybridizing the process by low frequency vibrations The object of the tool vibrations during the ECM process is to provide a new and improved method for ECM which;

1-Destroys the passivation layer and thereby controls the ECM action.

2-Utilize a reciprocal motion between the tool and workpiece to pump and consequently enhance the circulation of the electrolyte through the interface to permit the use of high current densities in order to improve the quality of the machined surface. 
The study highlights the development of general mathematical models for correlating the inter relationships of various machining parameters such as applied voltage, feed rate, back pressure and vibration amplitude on overcut and conicity for achieving high controlled accuracy. This work has been established based on the response surface methodology (RSM) approach.

\section{EXPERIMENTAL WORK}

This study attempts to utilize a reciprocal motion between the tool and the workpiece to pump and enhance the circulation of the electrolyte to improve ECM machining accuracy. A special drilling test rig has been constructed as shown diagrammatically in Fig.1. The main elements of the test rig are the machining cell unit (Fig. 2), low frequency electromagnetic vibrator, tool feed mechanism, hydraulic system and control unit.

\begin{tabular}{|c|l|}
\hline 1 & DC power supply \\
\hline 2 & Machining cell \\
\hline 3 & Exciter \\
\hline 4 & Reduction unit \\
\hline 5 & DC motor \\
\hline 6 & Controller \\
\hline 7 & Electrolyte tank \\
\hline 8 & Return tank \\
\hline 9 & Filter \\
\hline
\end{tabular}

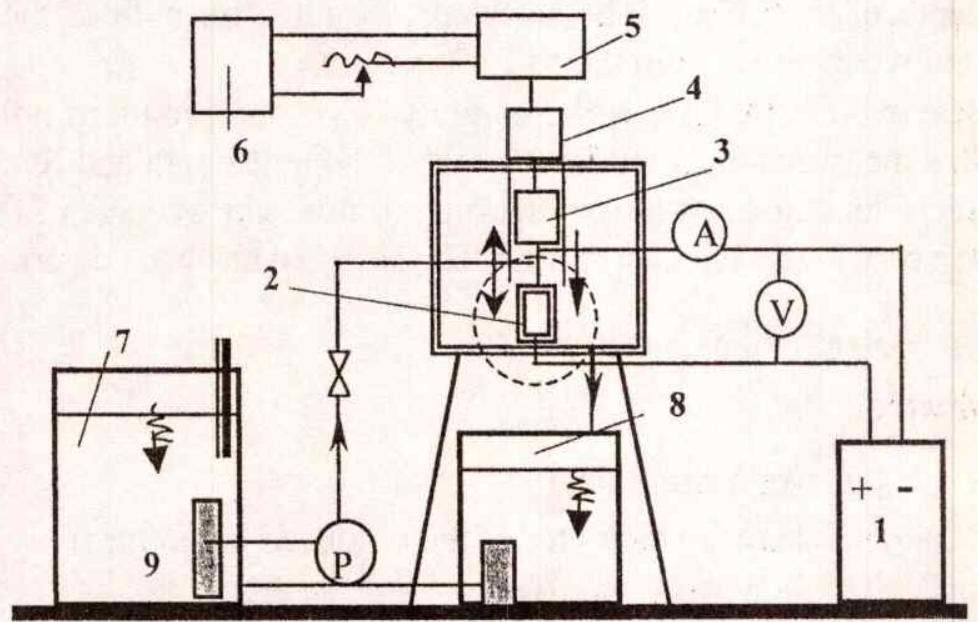

Fig.1. Schematic diagram of the experimental set-up.

\begin{tabular}{|l|l|}
\hline 1 & Electrolyte inlet \\
\hline 2 & Tool \\
\hline 3 & Electrolyte outlet \\
\hline 4 & Workpiece \\
\hline 5 & Cell case \\
\hline 6 & Workpiece copper base \\
\hline 7 & Cell base \\
\hline 8 & Anode wire holder \\
\hline 9 & O-ring \\
\hline
\end{tabular}

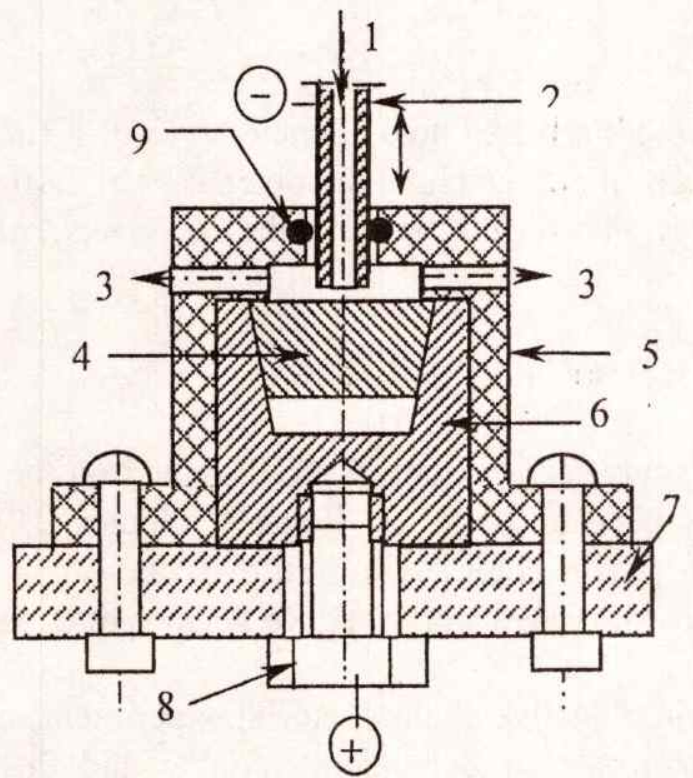

Fig. 2. Machining closed cell. 
The tool was made from brass with a circular cross section of $8 \mathrm{~mm}$ as out side diameter and $3.5 \mathrm{~mm}$ as inside diameter and a tool land of $1.5 \mathrm{~mm}$. The tool was externally insulated with a thin layer using epoxy resin to avoid undesired side cutting. Electrolyte was axially fed to the cutting zone through a central hole of $3.5 \mathrm{~mm}$ diameter. The experimental machining testes have been carried out using $200 \mathrm{~g} / \mathrm{l}$ of $\mathrm{NaCl}$ as an electrolyte under an inlet pressure of 0.25 $\mathrm{MPa}$ and flow rate of $6 \mathrm{l} / \mathrm{min}$. The outlet pressure of the machining closed cell was ranged from 0.01 to $0.05 \mathrm{MPa}$.

The vibrating motion of the tool was achieved using electromagnetic vibrator with $50 \mathrm{~Hz}$ as a vibration frequency and adjustable vibration amplitude. The amplitudes of tool vibrations were selected by using a calibrated nut, which limits the motion of the armature of the vibrator. The amplitudes were measured during the machining process using a $10 \mu \mathrm{m}$ dial gauge attached with the tool. The different amplitudes used, ranged from $20 \mu \mathrm{m}$ to $100 \mu \mathrm{m}$ (peak to peak). The tool holder was coupled to the electromagnetic head. The vibrator together with the tool can move through a guide way of chosen length to control the desired depth of machining. The selected feed rates for both of the electromagnetic vibrator and the tool were varied from 0.6 to $1.4 \mathrm{~mm} / \mathrm{min}$.

The overcut (O.C) and the conicity $(\delta)$ of the produced hole were determined. The diameter was measured at equall five levels of the hole depth and five positions of the hole diameter for every level using a horizontal microscope. The average of the sum of the measured diameters at every level was determined. The side gap has been determined as follows;

$$
Y_{e}=0.5\left(D_{w p}-D_{t}\right)
$$

where:

$Y_{e}:$ side gap, $(\mathrm{mm})$

$D_{w p}:$ mean diameter of the produced hole, $(\mathrm{mm})$

$D_{t}:$ tool diameter, $(\mathrm{mm})$

The produced hole conicity was calculated as follows:

$$
\delta=\left(\frac{D_{1}-D_{2}}{2 H}\right) 100 \%
$$

where:

$\delta$ : Conicity $(\%)$,

$D_{1}$ : Produced hole diameter at level $1,(\mathrm{~mm})$,

$D_{2}$ : Produced hole diameter at level 2, $(\mathrm{mm})$,

$H$ : The height between the two levels, (mm).

\section{DESIGN OF EXPERIMENTS}

In this study, experiments were designed on the basis of the experimental design technique that has been proposed by Box and Hunter (18). A $2^{k}$ factorial, where $\mathrm{k}$ is the number of variables, with central composite-second-order rotatable design was used to improve the reliability of results and to reduce the size of experimentation without loss of accuracy.

The main objective of the factorial experiments consists of studying the relationship between the response as a dependent variable and the parameter levels. This approach helps to understand better how the change in the levels of application of a group of parameters affects 
the response. A combination of the levels of the parameter, which leads to certain optimum response, can also be located through this approach.

It has been reported (18) that the factorial experiments provide an opportunity to study not only the individual effects of each factor but also their interactions. When experiments are conducted factor by factor while changing the level of each factor, the effect of interaction cannot be investigated. The factorial experiments have the further advantage of making experiments more economical.

Table 1. Coding of process parameters.

\begin{tabular}{|c|c|c|c|c|}
\hline $\begin{array}{c}\text { Coded } \\
\text { levels }\end{array}$ & $\begin{array}{c}\text { Feed }(f) \\
(\mathrm{mm} / \mathrm{min})\end{array}$ & $\begin{array}{c}\text { Applied } \\
\text { voltage } \\
(v)(\text { volts })\end{array}$ & $\begin{array}{c}\text { Amplitude } \\
(\mathrm{a})(\mu \mathrm{m})\end{array}$ & $\begin{array}{c}\text { Back } \\
\text { pressure } \\
(\mathrm{P}) \mathrm{MPa}\end{array}$ \\
\hline-2 & 0.6 & 12 & 20 & 0.01 \\
\hline-1 & 0.8 & 15 & 40 & 0.02 \\
\hline 0 & 1 & 18 & 60 & 0.03 \\
\hline+1 & 1.2 & 21 & 80 & 0.04 \\
\hline+2 & 1.4 & 24 & 100 & 0.05 \\
\hline
\end{tabular}

Table 2. Experimental design matrix and results.

\begin{tabular}{|c|c|c|c|c|c|c|c|c|c|c|}
\hline $\begin{array}{l}\text { Exp. } \\
\text { No. }\end{array}$ & \multicolumn{2}{|c|}{$\begin{array}{l}\text { Feed rate } \\
\text { code actual } \\
\left(x_{l}\right) \mathrm{mm} / \mathrm{min}\end{array}$} & \multicolumn{2}{|c|}{$\begin{array}{l}\text { Applied voltage } \\
\text { coder actual } \\
\left(x_{2}\right) \quad \text { volt }\end{array}$} & \multicolumn{2}{|c|}{$\begin{array}{l}\text { Amplitude } \\
\text { code actual } \\
\left(x_{3}\right) \quad \mu \mathrm{m}\end{array}$} & \multicolumn{2}{|c|}{$\begin{array}{l}\text { Back pressure } \\
\text { code actual } \\
\left(x_{4}\right) \quad \mathrm{MPa}\end{array}$} & $\begin{array}{c}\text { overcut } \\
\mathrm{mm}\end{array}$ & $\begin{array}{c}\text { conicity } \\
\delta\end{array}$ \\
\hline 1 & -1 & 0.8 & -1 & 15 & -1 & 40 & -1 & 0.02 & 1.2829 & 4.1 \\
\hline 2 & +1 & 1.2 & -1 & 15 & -1 & 40 & -1 & 0.02 & 0.5819 & 3.8 \\
\hline 3 & -1 & 0.8 & +1 & 21 & -1 & 40 & -1 & 0.02 & 1.3239 & 3.9 \\
\hline 4 & +1 & 1.2 & +1 & 21 & -1 & 40 & -1 & 0.02 & 0.5909 & 3.7 \\
\hline 5 & -1 & 0.8 & -1 & 15 & +1 & 80 & -1 & 0.02 & 1.3129 & 3.6 \\
\hline 6 & +1 & 1.2 & -1 & 15 & +1 & 80 & -1 & 0.02 & 0.5954 & 3.35 \\
\hline 7 & -1 & 0.8 & +1 & 21 & +1 & 80 & -1 & 0.02 & 1.3374 & 3.5 \\
\hline 8 & +1 & 1.2 & +1 & 21 & +1 & 80 & -1 & 0.02 & 0.6669 & 3.2 \\
\hline 9 & -1 & 0.8 & -1 & 15 & -1 & 40 & +1 & 0.04 & 1.2994 & 3.7 \\
\hline 10 & +1 & 1.2 & -1 & 15 & -1 & 40 & +1 & 0.04 & 0.5944 & 3.6 \\
\hline 11 & -1 & 0.8 & +1 & 21 & -1 & 40 & +1 & 0.04 & 1.3488 & 3.65 \\
\hline 12 & +1 & 1.2 & +1 & 21 & -1 & 40 & +1 & 0.04 & 0.6329 & 3.5 \\
\hline 13 & -1 & 0.8 & -1 & 51 & +1 & 80 & +1 & 0.04 & 1.3189 & 3.45 \\
\hline 14 & +1 & 1.2 & -1 & 15 & +1 & 80 & +1 & 0.04 & 0.5944 & 3.25 \\
\hline 15 & -1 & 0.8 & +1 & 21 & +1 & 80 & +1 & 0.04 & 1.5604 & 3.4 \\
\hline 16 & +1 & 1.2 & +1 & 21 & +1 & 80 & +1 & 0.04 & 0.7982 & 3.17 \\
\hline 17 & -2 & 0.6 & 0 & 18 & 0 & 60 & 0 & 0.03 & 1.8514 & 3.65 \\
\hline 18 & +2 & 1.4 & 0 & 18 & 0 & 60 & 0 & 0.03 & 0.4334 & 3.2 \\
\hline 19 & 0 & 1 & -2 & 12 & 0 & 60 & 0 & 0.03 & 1.0414 & 3.3 \\
\hline 20 & 0 & 1 & +2 & 24 & 0 & 60 & 0 & 0.03 & 1.2469 & 3.35 \\
\hline 21 & 0 & 1 & 0 & 18 & -2 & 20 & 0 & 0.03 & 1.0739 & 3.95 \\
\hline 22 & 0 & 1 & 0 & 18 & +2 & 100 & 0 & 0.03 & 1.1912 & 3.25 \\
\hline 23 & 0 & 1 & 0 & 18 & 0 & 60 & -2 & 0.01 & 1.2119 & 3.45 \\
\hline 24 & 0 & 1 & 0 & 18 & 0 & 60 & +2 & 0.05 & 1.2814 & 3.4 \\
\hline 25 & 0 & 1 & 0 & 18 & 0 & 60 & 0 & 0.03 & 1.2079 & 3.3 \\
\hline 26 & 0 & 1 & 0 & 18 & 0 & 60 & 0 & 0.03 & 1.1469 & 3.45 \\
\hline 27 & 0 & 1 & 0 & 18 & 0 & 60 & 0 & 0.03 & 1.2579 & 3.5 \\
\hline 28 & 0 & 1 & 0 & 18 & 0 & 60 & 0 & 0.03 & 1.2037 & 3.35 \\
\hline 29 & 0 & 1 & 0 & 18 & 0 & 60 & 0 & 0.03 & 1.1274 & 3.35 \\
\hline 30 & 0 & 1 & 0 & 18 & 0 & 60 & 0 & 0.03 & 1.2684 & 3.3 \\
\hline 31 & 0 & 1 & 0 & 18 & 0 & 60 & 0 & 0.03 & 1.1709 & 3.3 \\
\hline
\end{tabular}


The present investigation studied the results of the effects of feed rate $(f)$, applied voltage $(v)$, tool vibration amplitude (a) and back pressure (P) on hole conicity $(\delta)$ and overcut (O.C.) during the ECM process. A $2^{\mathrm{k}}$ factorial with central composite- second-order rotatable design was used (in this case $\mathrm{k}=4$ ).

This consists of $\mathrm{n}_{\mathrm{c}}=2^{\mathrm{k}}=16$ corner points at +1 level, $\mathrm{n}_{\mathrm{a}}=2 \mathrm{k}=8$ axial points at $\gamma=+2$, and a center point at zero level repeated 7 times $\left(\mathrm{n}_{0}\right)$ to estimate the pure error, where, the value of constant 1 at four independent variables is 0.86 (18). This involves a total of 31 experimental observations.

The values of coded and actual value of each parameter used in this work are listed in Table (1). The experimental matrix that was adopted in the present study in the coded form is shown in Table (2). The coded number for variables used in Tables (1) and (2) are obtained from the following transformation equations:

Feed rate.

$$
x_{1}=\frac{f-f_{0}}{\Delta f},
$$

Applied voltage

$$
x_{2}=\frac{v-v_{O}}{\Delta v} \text {, }
$$

Tool vibration amplitude,

$$
x_{3}=\frac{a-a_{0}}{\Delta a} \text {, }
$$

Back pressure,

$$
x_{4}=\frac{P-P_{O}}{\Delta P} \text {, }
$$

where $x_{1}, x_{2}, x_{3}$, and $x_{4}$ are the coded values of the variables $f, v, a$, and $\mathrm{P}$, respectively. $f_{o}, v_{o}$, $\mathrm{a}_{0}$, and $\mathrm{P}_{0}$ are the values of feed rate, applied voltage, tool vibration amplitude and back pressure at zero level. $\Delta f, \Delta v, \Delta a$, and $\Delta P$, are the units or intervals of variation in $f, v, a$, and $P$, respectively.

\section{RESPONSE SURFACE MODELING}

Response surface methodology (RSM) approach is the procedure for determining the relatioship between various process prameters with the various machining criteria and exploring the effect of these process parameters on the coupled responses (19-20), i.e. the over cut and conicity. In order to study the effect of the ECM parameters on the obovementioned two most accuracy criteria (the over cut, OC, and conicity,), a second- order polynomial response can be fitted into the following equation of (18):

$$
Y_{u}=b_{O}+\sum_{i=1}^{k} b_{i} x_{i}+\sum_{i=1}^{k} b_{i i} x_{i}^{2}+\sum_{j>i}^{k} b_{i j} x_{i} x_{j}
$$

where; $Y_{u}$ is the response and the $\mathrm{x}_{\mathrm{i}}(1,2, \ldots \mathrm{k})$ are coded level of $\mathrm{k}$ quantitative variables. The coefficient $b_{0}$ is the free term, the coefficients $b_{i}$ are the linear terms, the coefficients $b_{i i}$ are the quadratic terms, and the coefficients $b_{i j}$ are the interaction terms. Applying the least squares technique the values of these coefficients can be estimated by using the observations collected $\left(Y_{1}, Y_{2}, \ldots, Y_{N}\right)$ through the design points $(N)$. This equation can be rewritten according to the four variables in the coded form:

$$
\begin{aligned}
Y_{u}= & b_{o}+b_{1} x_{1}+b_{2} x_{2}+b_{3} x_{3}+b_{4} x_{4}+b_{11} x_{1}^{2}+b_{22} x_{2}^{2}+b_{33} x_{3}^{2}+b_{44} x_{4}^{2}+b_{12} x_{1} x_{2}+ \\
& b_{13} x_{1} x_{3}+b_{14} x_{1} x_{4}+b_{23} x_{2} x_{3}+b_{24} x_{2} x_{4}+b_{34} x_{3} x
\end{aligned}
$$




\subsection{Model for overcut}

Using the results presented in Table (2), the form of the derived model is as follows:

$$
\begin{aligned}
\text { O. C. } & =1.1824-0.357 x_{1}+0.0461 x_{2}+0.032 x_{3}+0.0249 x_{4}-0.0425 x_{1}{ }^{2}-0.042 x_{2}{ }^{2} \\
& -0.0449 x_{3}^{2}-0.0164 x_{4}^{2}-0.0018 x_{1} x_{2}-0.0015 x_{1} x_{3}-0.0061 x_{1} x_{4}+0.0258 x_{2} x_{3} \\
& +0.0239 x_{2} x_{4}+0.0154 x_{3} x_{4}
\end{aligned}
$$

The equation was tested to show the significant parameters by applying the student's T-test. F-ratio test was also used to improve the fitting of the equation and it can be written as:

$$
\begin{aligned}
\text { O.C. }= & 1.1824-0.357 x_{1}+0.0461 x_{2}+0.032 x_{3}+0.0249 x_{4}-0.0425 x_{1}^{2}-0.042 x_{2}^{2}- \\
& 0.0449 x_{3}^{2}-0.0258 x_{2} x_{3}
\end{aligned}
$$

\subsection{Model for conicity}

Using the results presented in Table (4-5), the form of the derived model is as follows:

$$
\begin{aligned}
\delta= & 3.548-0.14 x_{1}+0.005 x_{2}-0.141 x_{3}-0.04 x_{4}-0.019 x_{1}^{2}-0.051 x_{2}^{2}+0.0001 x_{3}^{2} \\
& -0.026 x_{4}{ }^{2}+0.044 x_{1} x_{2}+0.026 x_{1} x_{3}+0.063 x_{1} x_{4}-0.036 x_{2} x_{3}-0.036 x_{2} x_{4}- \\
& 0.005 x_{3} x_{4}
\end{aligned}
$$

The equation was tested to show the significant parameters by applying the student's T-test F-ratio test was also used to improve the fitting of the equation and it can be written as:

$$
\delta=3.548-0.14 x_{1}-0.141 x_{3}-0.051 x_{2}^{2}
$$

The mathematical models obtained earlier were analyzed and plotted to study the influence of process parameters on the two responses O.C. and $\delta$. These results are discussed under various response parameters.

\section{RESULTS AND DISCUSSIONS}

\subsection{Effect of machining parameters on overcut}

Based on the mathematical model given by eqns. (9) and (10), to study the effects of various process parameters on O.C. in order to analyze the suitable parametric combinations that can be made for achieving controlled O.C. effects. To make a fair comparison, the results of zero amplitude have also been presented. Figures (3), (4) and (5) show the effect of tool feed rates, applied voltages, and back pressures on the overcut value at different vibration amplitudes.

From Fig. (3) it can be noted that the feed rate has a significant effect on overcut value at different vibration amplitudes. This is in agreement with the interactive effects of the process parameters and physicochemical phenomenal changes under such controlled operating conditions. 
Figure (4) shows that O. C. value increases non-linearly with increase in the applied voltage for every vibration amplitude. This is because increase in the voltage at particular vibration amplitude causes greater electrolyzing current to be available in the machining gap, as well as causing a greater stray current intensity.

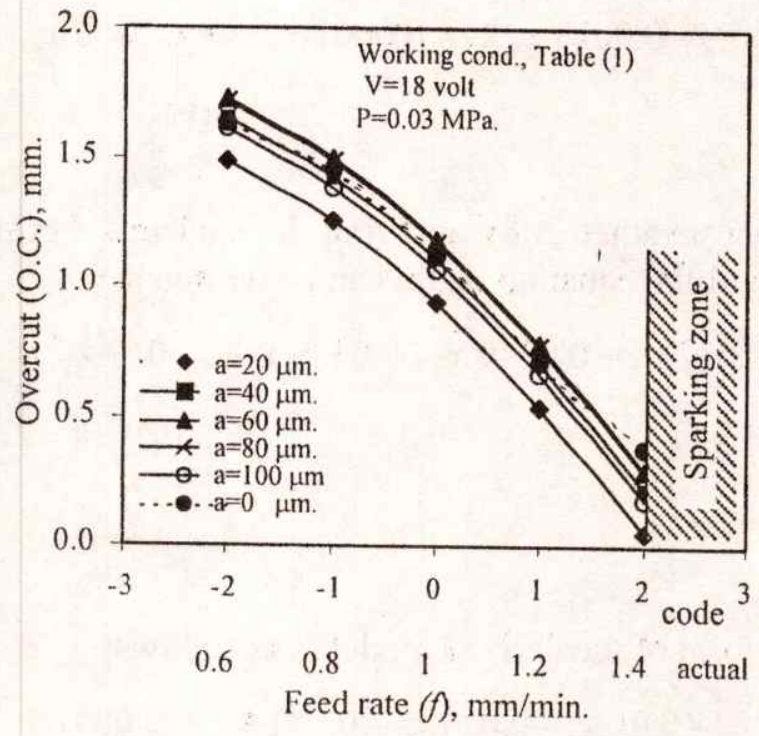

Fig.3 Effect of feed rate on overcut at different amplitudes.

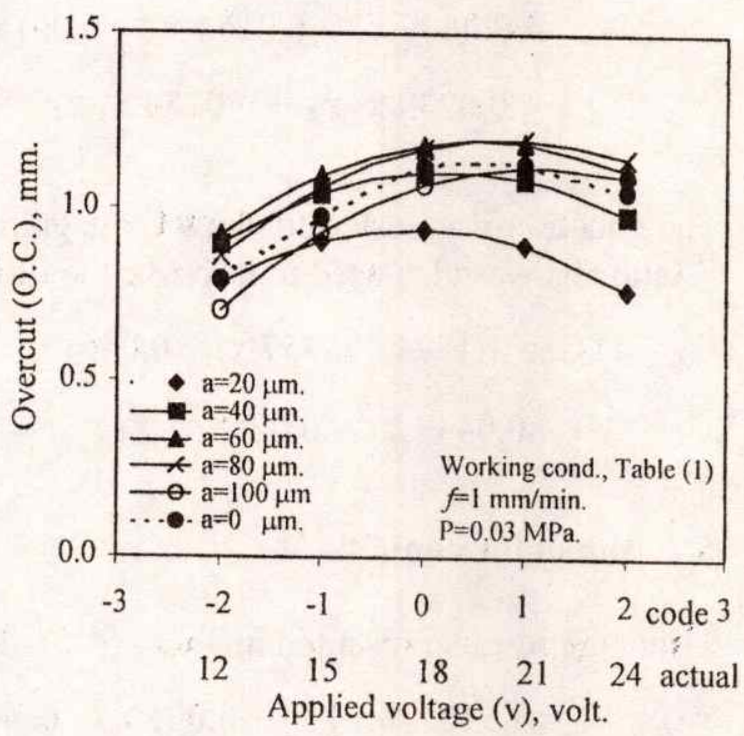

Fig.4 Effect of applied voltage on overcut at different amplitudes.

Figure (5) shows the pattern of variation of the effect of the back pressure on the overcut value. It is clear from the trend of the figures that back pressure has an insignificant effect on the overcut value. This result has been attributed to the relatively wide value of the side gap.

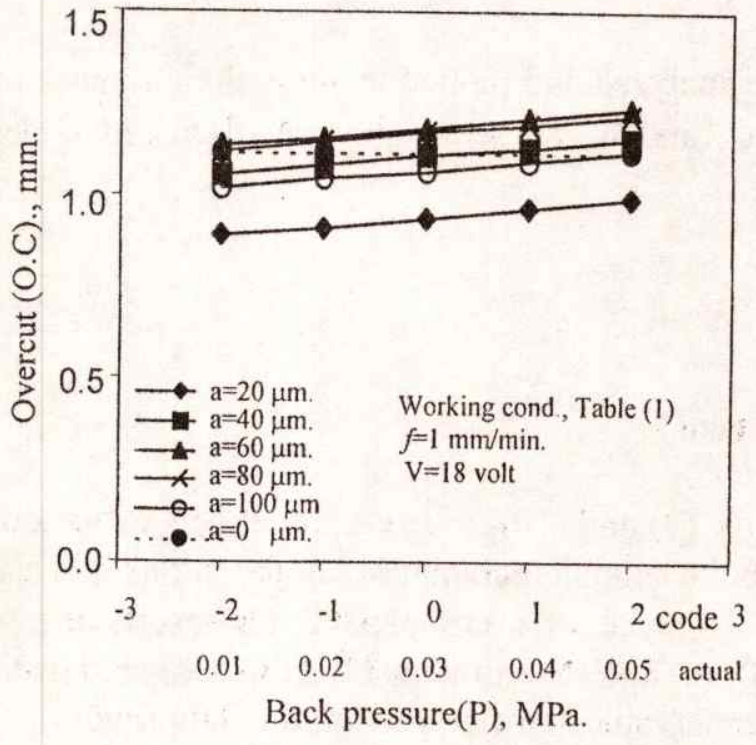

Fig. 5 Effect of back pressure on overcut at different amplitudes.

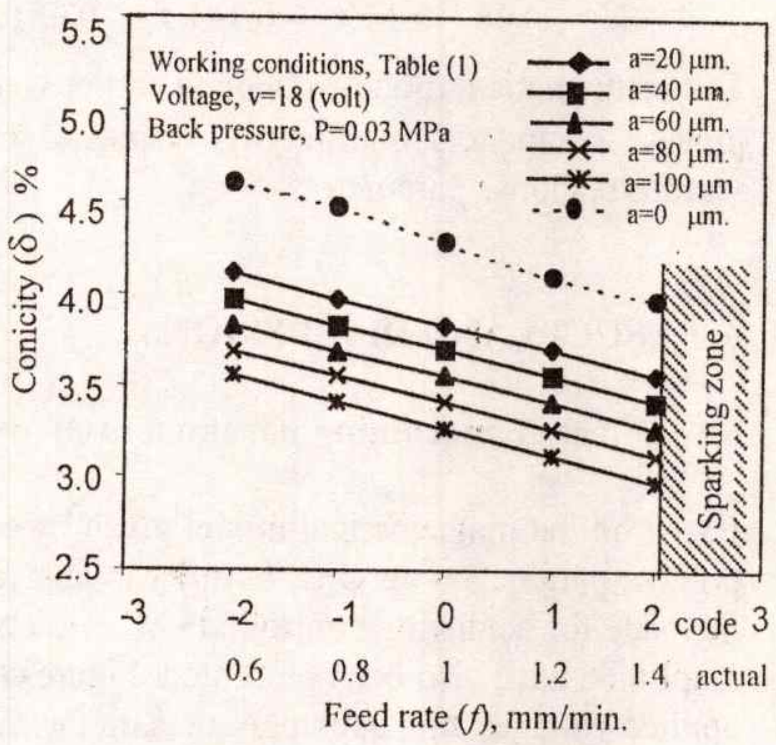

Fig. 6 Effect of feed rate on conicity at various amplitudes.

The figures indicate that the significant effect of the tool amplitude value on the overcut value is pronounced at the lowest tool amplitude values. This result is due to that the higher tool 
Figure (4) shows that O. C. value increases non-linearly with increase in the applied voltage for every vibration amplitude. This is because increase in the voltage at particular vibration amplitude causes greater electrolyzing current to be available in the machining gap, as well as causing a greater stray current intensity.

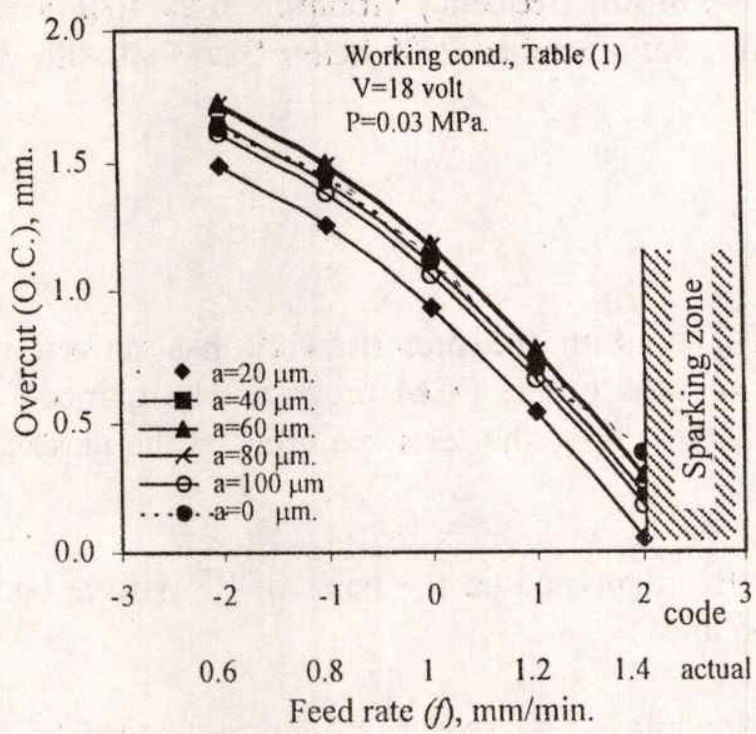

Fig.3 Effect of feed rate on overcut at different amplitudes.

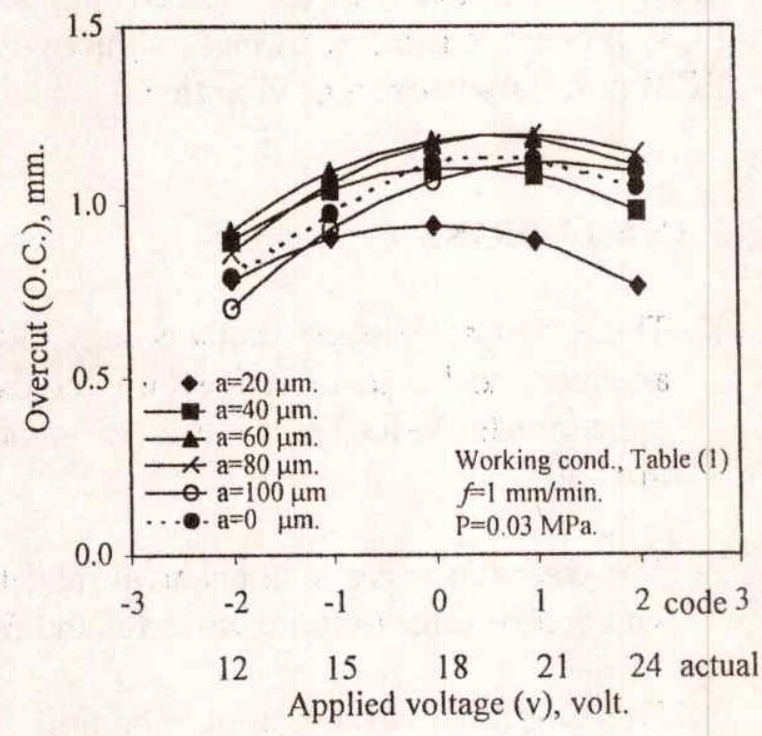

Fig.4 Effect of applied voltage on overcut at different amplitudes.

Figure (5) shows the pattern of variation of the effect of the back pressure on the overcut value. It is clear from the trend of the figures that back pressure has an insignificant effect on the overcut value. This result has been attributed to the relatively wide value of the side gap.

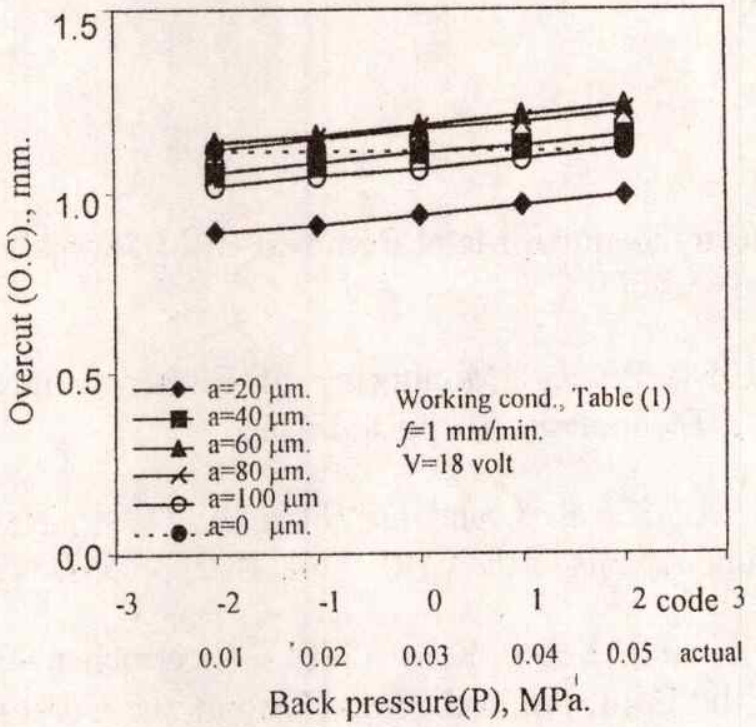

Fig. 5 Effect of back pressure on overcut at different amplitudes.

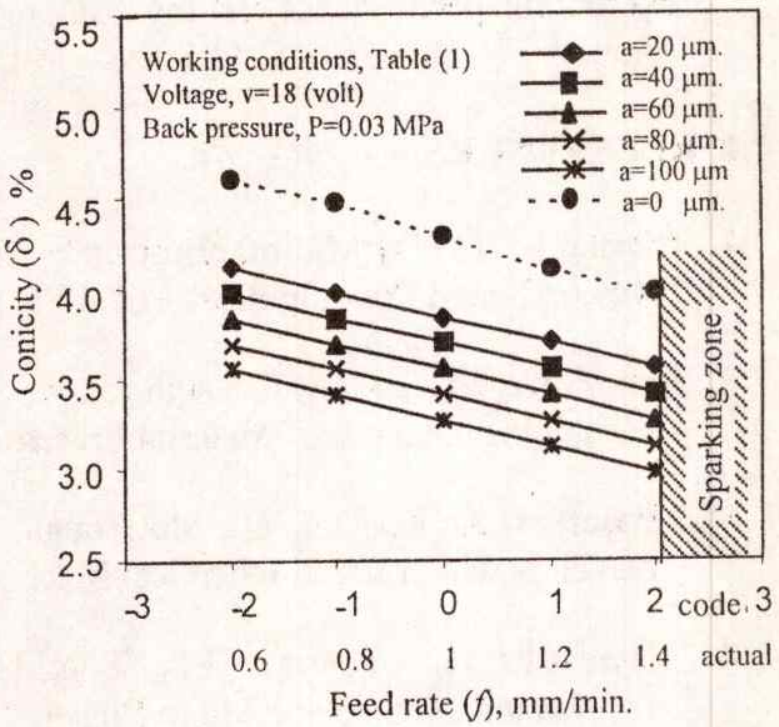

Fig. 6 Effect of feed rate on conicity at various amplitudes.

The figures indicate that the significant effect of the tool amplitude value on the overcut value is pronounced at the lowest tool amplitude values. This result is due to that the higher tool 
effect on improving the conicity of the produced hole. This effect is due to the powerful of the pumping action at the frontal zone. This result is related to the intense of the flushing of the inter-electrode gap with the fresh electrolyte and evacuation of the machining products. This leads to the decrease the effect of the unnecessary machining at the wall side and accordingly improves the conicity of the hole. The application of low frequency vibration to the tool in the ECM process reduced workpiece conicity with a ratio reached $23 \%$ better than that with the ECM process without tool vibrations.

\section{COCLUSIONS}

1- The response surface methodology (RSM) used in the present work has proved its adequecy to be an effective tool for the analysis of the ECM process. The number of experiments performed by this technique were $5 \%$ of the tests required by the classical methods.

2- The comprehensive mathematical models thus devolped on the basis of RSM have been found to be quite unique, powerful and flexiable.

3- The amplitude of the tool vibration is the most effective parameter affecting ECM accuracy. However, this effect diminishes after the tool amplitude reaches $80 \mu \mathrm{m}$..

4- In the ECM assisted by low frequency vibrations, product accuracy has been improved with a ratio reaching $15 \%$ and workpiece wall conicity has decreased with a ratio of $23 \%$.

5- The present results are useful for both design and production engineers to assess the necessary information about tool vibration in ECM processes to achieve beneficial operational performance and low equipment costs.

\section{REFERENCES}

1. Datta, M. (1998) Microfabrication by Electrochemical Metal Removal. IBM Journal of Research and Development, Vol. 42/5, pp.655-669.

2. De Silva, A. and McGeough, J. A. (1998) Process Monitoring of Electrochemical Machining. Journal of Material Processing Technology, 76, pp.165-169.

3. Rajurkar, K. P., Thu, D., McGeough, J. A., Kozak J. and De Silva, A. (1999) New Development in Electrochemical Machining. Annals of the CIRP, Vol. 48/2, pp.567-579.

4. Hyung, J. L., Young, M.L., Soo, H.K. and Yoon, K.K. (2001) Electrochemical Fabrication Method for Micro Punch, $7^{\text {th }}$ Int.Conf. on Prod. Engg. Design and Control, pp.1097-1103.

5. Rajurkar, K. P., Kozak, J. and Wei, B. (1993) Study of Pluse Electrochemical Machining Characterizitics. Annals of CIRP, Vol. 42/1, pp. 231-234.

6. McGeough, J. A. (1974) Principles of Electrochemical Machining. Chapman and Hall, London. 
7. Bannard, J. (1977) Electrochemical Machining. Journal of Applied Electrochemistry, 7, pp. 1-29.

8. Ghabrial, S. R. and Ebeid, S. J. (1981) Beneficial Effect of Air-Electrolyte Mixtures in Stationary ECM. Precision Engg. 0141-6, 359/040, pp. 221-223.

9. Rumyantsev, E. and Davedov, A. (1989) Electrochemical Machining of Metals. Mir Publishers, Moscow.

10. Rajurkar, K. P. Zhu, D., McGeough, J. A., Kozak, J. and De Silva, A. (1999) New Development in Electrochemical Machining. Annals of the CIRP, Vol. 48/2, pp. 567579.

11. Hewidy, M. S., Ebeid, S. J., Rajurkar, K. P. and El-Safti, M. F. (2001) Electrochemical Machining under Orbital Motion Conditions. J. of Material Processing Technology, 109, pp. 339-346.

12. Rajurkar, K. P. and Zhu, D. (1999) Improvement of Electrochemical Machining Accuracy by using Orbital Electrode Movement. Annals of CIRP, Vol. 48/1, pp.139-142.

13. Kozak, J. and K. P. Rajurkar (2001) Laser Assisted Electrochemical Machining. Transactions of the North American Manufacturing Research Institution of SME (NAMRI/SME), Vol. XXIX, pp.421-427.

14. Kozak, J. (1996) Selected Problems of Hybrid Electro-Mechanical Machining. Archives of Mechanical Technology and Automatization, Vol. 16, pp. 59-65.

15. Kozak, J. and Rajurkar, K. P. (2000) Hybrid Machining Process Evaluation and Development. Keynote Paper, Proc. $2^{\text {nd }}$ Int. Conf. on Machining and Measurements of Sculptured Surfaces, Kraków, Poland, pp. 501-536.

16. Kozak, J., Rajurkar, K. P. and Malicki, S. (2000) Study of Electrochemical Machining Utilizing a Vibrating Tool Electrode. Proc. of the 16th Int. Conf. on Computer Aided Production Engineering CAPE, Edinburg, U. K., pp.173-181.

17. Ebeid, S. J. Hewidy, M. S. El-Taweel T. A. and Youssf, A. H. (2003) ECM Assisted by Low-Frequency Vibrations. Proceedings of the $20^{\text {th }}$ International Manufacturing Conf. (IMC-20), Cork, Ireland, Sept. 3-5, pp.541-549.

18. Das, M. N. and Giri, N. G. (1986) Design and Analysis of Experiments. Wiley and Sons, New York, Second Edition.

19. Hewidy, M. S. and Fattouh, M. (1989) Electrochemical Cutting using Tubular Cathodes: Response Surface Approach. WT. J. Prod. Res., Vol. 27, No. 6, pp. 953-963.

20. Bhattacharyya, B. and Sorkhel, S. K. (1999) Investigation for Controlled Electrochemical Machining Through Response Surface Methodology-Based Approach. Journal of Material Processing Tech. 86, pp. 200-207. 


\section{نحو دقة أعلى للتشغيل الكهروكيميائى المهجن بالإهتزازات منثفضة التردد بإستخدام نسق الإستجابة السطىى}

\section{ملخص البمث}

بالرغم من المز ايا العديدة التى تقدمها عملية التشغيل الكهروكيمبائى فى مجال تشغيل المعادن وخاصن وخاصة

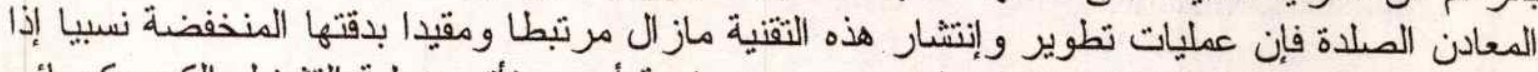

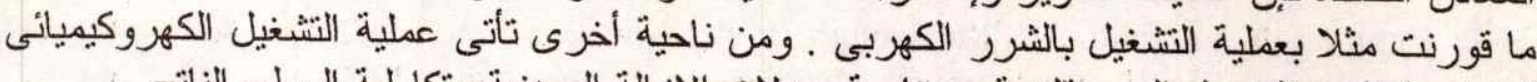

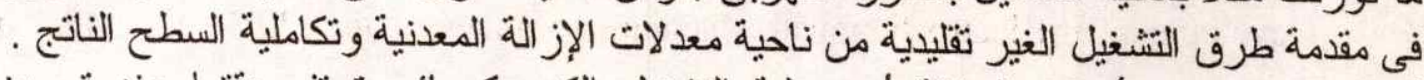

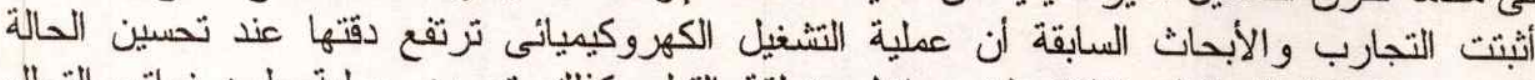

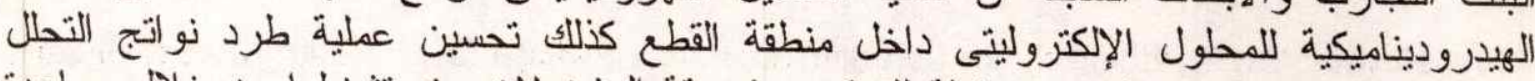

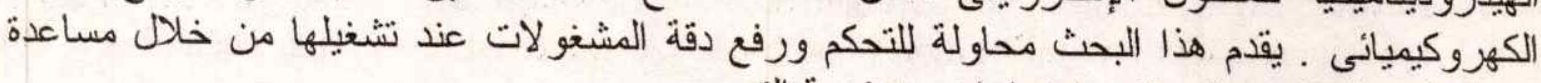

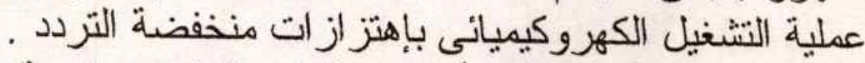

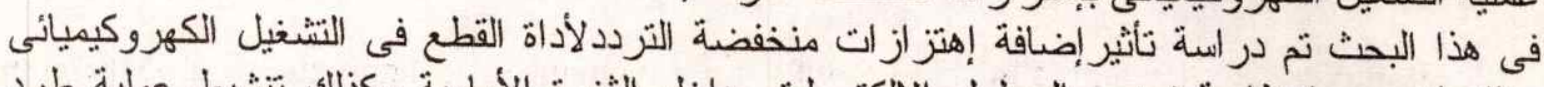

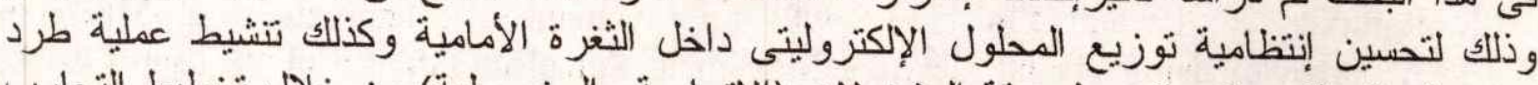

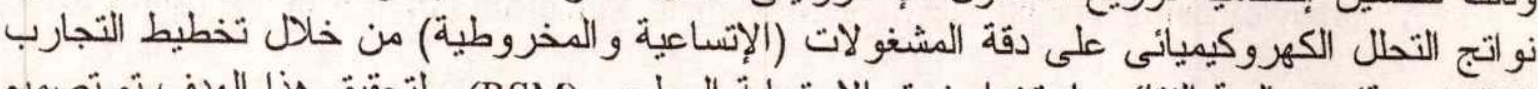

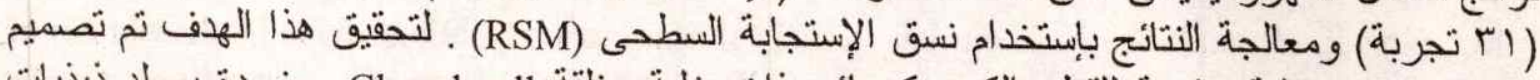

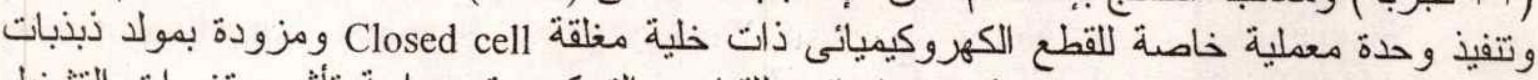

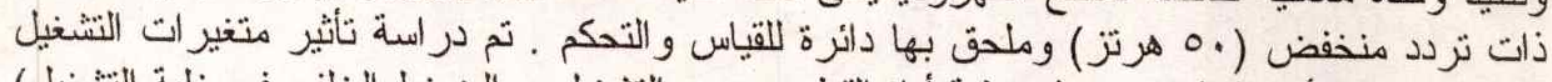

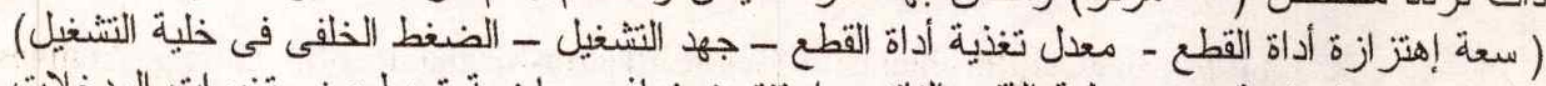

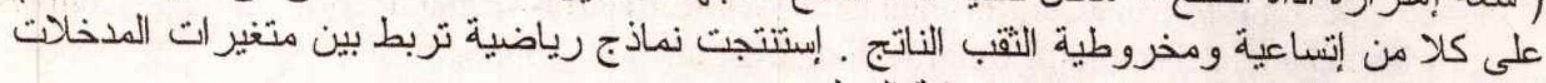
و المخرجات وذللك بإستخدام نسق الإستجابة السطحى .

ا- أثبتت طريقة نسق الإستجابة السطحى فعاليتها فى تحليل نتائج النشغيل الكهروكيميائى وقد

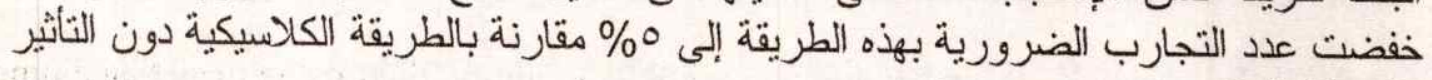
r- أظهرت النماذج الرياضية المستنتجة بطريقة نسق الإستجابة السطحى مرونة وفعالية فى الثبؤ

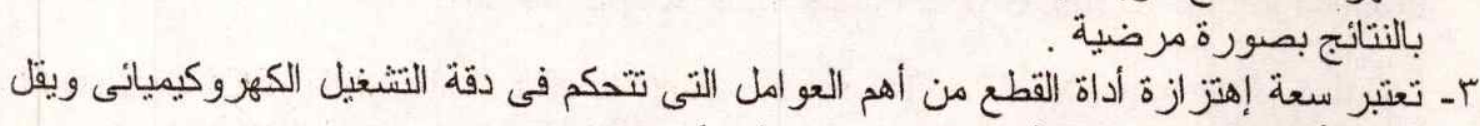

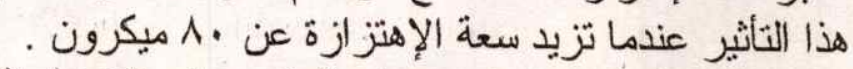

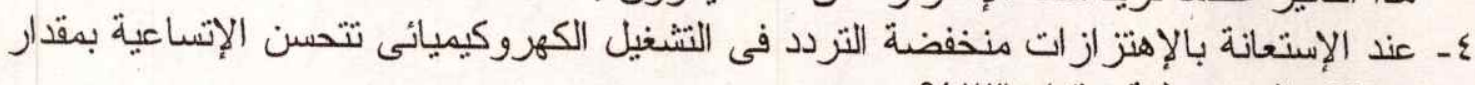

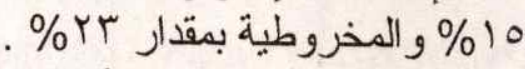

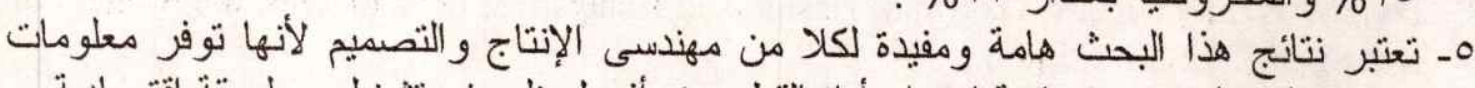
ضرورية حول إستخدام تقنية إهتز از أداة القطع عند أفضل ظروف الإنتاج تشغيل وبطريقة إقتصادية . 